\title{
1 Causal associations between body fat accumulation and COVID-19 severity: A
}

\section{Mendelian randomization study}

4 Satoshi Yoshiji ${ }^{1-4}$, Daisuke Tanaka ${ }^{1}$, Hiroto Minamino ${ }^{1,4}$, Takaaki Murakami ${ }^{1}$, Yoshihito Fujita ${ }^{1}$,

5 J. Brent Richards ${ }^{2,3,5-8 \dagger}$, and Nobuya Inagaki ${ }^{1 \dagger}$

6

$7{ }^{1}$ Department of Diabetes, Endocrinology and Nutrition, Graduate School of Medicine, Kyoto

8 University, Kyoto, Japan

$9 \quad{ }^{2}$ Department of Human Genetics, McGill University, Montréal, Québec, Canada

$10{ }^{3}$ Kyoto-McGill International Collaborative Program in Genomic Medicine, Graduate School of

11 Medicine, Kyoto University, Kyoto, Japan

$12{ }^{4}$ Japan Society for the Promotion of Science, Tokyo, Japan

$13{ }^{5}$ Centre for Clinical Epidemiology, Department of Medicine, Lady Davis Institute, Jewish

14 General Hospital, McGill University, Montréal, Québec, Canada.

$15{ }^{6}$ Department of Epidemiology, Biostatistics and Occupational Health, McGill University,

16 Montréal, Québec, Canada.

$17{ }^{7}$ Department of Twin Research, King's College London, London, United Kingdom.

$18{ }^{8} 5$ Prime Sciences, Montreal, Quebec, Canada.

$19{ }^{\dagger}$ These authors contributed equally to this study. 
medRxiv preprint doi: https://doi.org/10.1101/2022.01.20.22269593; this version posted January 21, 2022. The copyright holder for this preprint

(which was not certified by peer review) is the author/funder, who has granted medRxiv a license to display the preprint in perpetuity.

It is made available under a CC-BY 4.0 International license.

21 Short title: Body fat accumulation and COVID-19 severity

22 Keywords: COVID-19, body fat accumulation, body composition, Mendelian randomization

24 Correspondence

25 J. Brent Richards

26 Professor of Medicine, McGill University, Senior Lecturer, King's College London (Honorary),

27 Pavilion H-413, Jewish General Hospital, 3755 Côte-Ste-Catherine Montréal, Québec, H3T

28 1E2, Canada.

29 Tel: $+1-514-340-8222$

30 Fax: $+1-514-340-7529$

31 E-mail: brent.richards@mcgill.ca

33 Nobuya Inagaki

34 Professor and Chairman, Department of Diabetes, Endocrinology and Nutrition, Graduate

35 School of Medicine, Kyoto University, 54 Kawahara-cho, Shogoin, Sakyo-ku, Kyoto, 606-8507,

36 Japan.

37 Tel: $+81-075-751-3560$

38 Fax: $+81-075-751-4244$ 
39 E-mail: inagaki@kuhp.kyoto-u.ac.jp

40

41 Disclosure summary

42 JBR's institution has received investigator-initiated grant funding from Eli Lilly,

43 GlaxoSmithKline and Biogen for projects unrelated to this research. He is the founder of 5

44 Prime Sciences (www.5primesciences.com), which provides research services for biotech,

45 pharma and venture capital companies for projects unrelated to this research. NI received

46 research funds from Terumo Corp., Drawbridge, Inc., and Asken Inc. NI received speaker

47 honoraria from Kowa Co., Ltd., MSD K.K, Astellas Pharma Inc., Novo Nordisk Pharma Ltd.,

48 Ono Pharmaceutical Co., Ltd., Nippon Boehringer Ingelheim Co., Ltd., Takeda

49 Pharmaceutical Co., Ltd., Mitsubishi Tanabe Pharma Corp., Sumitomo Dainippon Pharma

50 Co., Ltd., Sanofi K.K., Eli Lilly Japan K.K.; received scholarship grant from Kissei

51 Pharmaceutical Co., Ltd., Sanofi K.K., Daiichi-Sankyo Co., Ltd., Mitsubishi Tanabe Pharma

52 Corp., Takeda Pharmaceutical Co., Ltd., Japan Tobacco Inc., Kyowa Kirin Co., Ltd.,

53 Sumitomo Dainippon Pharma Co., Ltd., Astellas Pharma Inc., MSD K.K., Ono Pharmaceutical

54 Co., Ltd., Sanwa Kagaku Kenkyusho Co., Ltd., Nippon Boehringer Ingelheim Co., Ltd., Novo

55 Nordisk Pharma Ltd., Novartis Pharma K.K., and Life Scan Japan K.K. NI is an advisory board

56 member of Novo Nordisk. These agencies did not play any role in study design; the collection, 
medRxiv preprint doi: https://doi.org/10.1101/2022.01.20.22269593; this version posted January 21, 2022. The copyright holder for this preprint (which was not certified by peer review) is the author/funder, who has granted medRxiv a license to display the preprint in perpetuity.

It is made available under a CC-BY 4.0 International license.

4

57 analysis, or interpretation of data; the writing of the report; or the decision to submit this paper

58 for publication. The other authors declare no conflict of interests.

59 
medRxiv preprint doi: https://doi.org/10.1101/2022.01.20.22269593; this version posted January 21, 2022. The copyright holder for this preprint

(which was not certified by peer review) is the author/funder, who has granted medRxiv a license to display the preprint in perpetuity.

It is made available under a CC-BY 4.0 International license .

\section{Abstract}

61 Purpose: The causal effects of body fat mass and body fat-free mass on coronavirus disease

622019 (COVID-19) severity remain unclear. Here, we used Mendelian randomization (MR) to

63 evaluate the causal relationships between body fat-related traits and COVID-19 severity.

64 Material and Methods: We identified single nucleotide polymorphisms associated with body

65 mass index (BMI) and direct measures of body fat (i.e., body fat percentage, body fat mass,

66 and body fat-free mass) in $461,460,454,633,454,137$, and 454,850 individuals of European

67 ancestry from the UK Biobank, respectively. We then performed two-sample MR to ascertain

68 their effects on severe COVID-19 (cases: 4,792; controls: 1,054,664) from the COVID-19 Host

69 Genetics Initiative.

70 Results: We found that an increase in BMI, body fat percentage, and body fat mass by one

71 standard deviation were each associated with severe COVID-19 (odds ratio $(O R)_{\mathrm{BMI}}=1.49$,

$7295 \% \mathrm{Cl}: 1.19-1.87, P=5.57 \times 10^{-4} ; \mathrm{OR}_{\text {body fat percentage }}=1.94,95 \% \mathrm{Cl}: 1.41-2.67, P=5.07 \times 10^{-5}$;

73 and $\left.\mathrm{OR}_{\text {body fat mass }}=1.61,95 \% \mathrm{Cl}: 1.28-2.04, P=5.51 \times 10^{-5}\right)$. Further, we evaluated

74 independent causal effects of body fat mass and body fat-free mass using multivariable MR

75 and revealed that only body fat mass was independently associated with severe COVID-19

$76\left(\mathrm{OR}_{\text {body fat mass }}=2.91,95 \% \mathrm{Cl}: 1.71-4.96, P=8.85 \times 10^{-5}\right.$ and $\mathrm{OR}_{\text {body fat-free mass }}=1.02,95 \% \mathrm{Cl}$ :

$77 \quad 0.61-1.67, P=0.945)$. 
medRxiv preprint doi: https://doi.org/10.1101/2022.01.20.22269593; this version posted January 21, 2022. The copyright holder for this preprint (which was not certified by peer review) is the author/funder, who has granted medRxiv a license to display the preprint in perpetuity. It is made available under a CC-BY 4.0 International license.

\section{6}

78 Conclusions: This study demonstrates the causal effects of body fat accumulation on

79 COVID-19 severity and indicates that the biological pathways influencing the relationship

80 between COVID-19 and obesity are likely mediated through body fat mass. 
medRxiv preprint doi: https://doi.org/10.1101/2022.01.20.22269593; this version posted January 21, 2022. The copyright holder for this preprint (which was not certified by peer review) is the author/funder, who has granted medRxiv a license to display the preprint in perpetuity.

It is made available under a CC-BY 4.0 International license .

81 Introduction

82 Coronavirus disease-19 (COVID-19) has infected hundreds of millions of individuals and

83 caused millions of deaths worldwide (1). The severity of COVID-19 varies considerably among

84 individuals, and identifying modifiable risk factors associated with COVID-19 severity is

85 essential for optimizing public health policies, allocating resources, and assisting clinical

86 decisions.

A major risk factor for COVID-19 appears to be obesity. A community-based cohort

88 study involving 6.9 million individuals in England showed a positive association between body

89 mass index (BMI) and COVID-19 severity (2). In that study, BMI was significantly associated

90 with hospital admission, admission to an intensive care unit, and death due to COVID-19, with

91 these findings being replicated in other independent observational studies $(3,4)$. However,

92 these results do not support causation; in fact, interpreting these observations as a causal

93 relationship relies on untestable and usually implausible assumptions, including the absence

94 of unmeasured confounders and reverse causation (5). Given these limitations inherent to

95 traditional observational epidemiology studies, Mendelian randomization (MR) has emerged

96 as a way to mitigate against such shortcomings through its use of genetic variants as

97 instrumental variables in order to infer a causal relationship between exposures and outcomes

$98(6,7)$. Using MR, we can estimate the causal effects of genetically predicted levels of

99 adiposity-related exposures on COVID-19 outcomes, in contrast to typical observational 
medRxiv preprint doi: https://doi.org/10.1101/2022.01.20.22269593; this version posted January 21, 2022. The copyright holder for this preprint (which was not certified by peer review) is the author/funder, who has granted medRxiv a license to display the preprint in perpetuity.

It is made available under a CC-BY 4.0 International license.

100 studies that evaluate only associations. Because genetic alleles are randomly assigned at

101 conception, which is generally well before the onset of the disease, the risk of reverse

102 causation is substantially decreased.

103 The selection of proxy measures of adiposity plays a vital role in evaluating the

104 association between obesity and COVID-19 outcomes. BMI can be measured easily and is

105 therefore a common measurement of obesity in epidemiological studies. However, the key

106 limitation of BMI is that it is an indirect measure of obesity because it is calculated only with

107 height and weight and does not consider body composition (i.e., body fat mass, body fat-free

108 mass, and their ratio) (8). Therefore, direct measures of body fat accumulation (i.e., body fat

109 percentage and body fat mass) might better elucidate the association of body fat with

110 COVID-19 outcomes. Taking this into consideration, we used a dataset of the UK Biobank,

111 which is a prospective cohort in the UK involving $~ 500,000$ individuals (463,844 of which are of

112 European ancestry) with detailed genetic and phenotypic information. Data from the UK

113 Biobank includes measurements of not only BMI but also body fat mass and body fat-free

114 mass acquired through the bioelectrical impedance analysis and dual-energy X-ray

115 absorptiometry along with the results from the genome-wide association studies (GWAS) for

116 these traits (9). Recent MR studies utilized the results from the UK Biobank to obtain single

117 nucleotide polymorphisms (SNPs) associated with body fat accumulation and showed

118 estimated causal effects of body fat on various traits ranging from cardiovascular diseases to 
medRxiv preprint doi: https://doi.org/10.1101/2022.01.20.22269593; this version posted January 21, 2022. The copyright holder for this preprint (which was not certified by peer review) is the author/funder, who has granted medRxiv a license to display the preprint in perpetuity.

It is made available under a CC-BY 4.0 International license.

119 depression (10-13). In light of these promising findings, body fat mass has emerged as a

120 valuable indicator of the deleterious effects of fat accumulation; however, it remains unclear

121 whether fat mass and fat percentage are causally related to severe outcomes of COVID-19.

122 In this study, we therefore conducted a two-sample MR to assess whether BMI and

123 direct measures of body compositions (i.e., body fat percentage, body fat mass, and body

124 fat-free mass) are causally associated with severe COVID-19 and COVID-19 hospitalization

125 using data from the UK Biobank and the COVID-19 Host Genetics Initiative.

\section{Methods}

128 Instrumental variables for BMI, body fat percentage, body fat mass, and body fat-free

129 mass

130 Instrumental variables were defined as independent genome-wide significant SNPs $(P<$

$1315 \times 10^{-8}$ ) for exposure traits. Independence of SNPs was defined as not in linkage

132 disequilibrium with other SNPs $\left(r^{2}<0.001\right.$ within a $10,000 \mathrm{~kb}$ window $)$. The exposures used in

133 this study were BMI, body fat percentage, body fat mass and body fat-free mass. To select

134 SNPs used as instrumental variables, we obtained the GWAS results of BMI, body fat

135 percentage, body fat mass, and body fat-free mass from individuals with European ancestry in

136 the UK Biobank (Figure 1), using the OpenGWAS and MR-Base platform of the MRC

137 Integrative Epidemiology Unit at the University of Bristol (14). The fat mass and fat-free mass 
medRxiv preprint doi: https://doi.org/10.1101/2022.01.20.22269593; this version posted January 21, 2022. The copyright holder for this preprint (which was not certified by peer review) is the author/funder, who has granted medRxiv a license to display the preprint in perpetuity.

It is made available under a CC-BY 4.0 International license .

138 of the UK Biobank participants were evaluated by performing bioelectrical impedance analysis

139 using the Tanita BC418MA body composition analyzer (Tanita, Tokyo, Japan). We restricted

140 the analyses to individuals of European ancestry in order to maximize the statistical power,

141 given that the majority of UK Biobank participants were of European ancestry. To select

142 instrumental variables, SNPs were clumped using PLINK (v1.90) according to a linkage

143 disequilibrium threshold of $r^{2}<0.001$ with a clumping window of $10,000 \mathrm{~kb}$ using the $1000 \mathrm{G}$

144 European reference panel $(9,14)$ in order to select an independent SNP with the lowest

$145 P$-value in each linkage disequilibrium block. When a selected SNP was not present in the

146 results of the GWAS on COVID-19 severity outcomes, we instead used a proxy SNP that was

147 in linkage disequilibrium with the selected SNP instead, with an $r^{2}$ of $\geq 0.8$ and minor allele

148 frequency of $\leq 0.3$ using 1000 G European reference panel as described elsewhere (12). We

149 calculated $F$-statistics for the exposure traits and a genetic correlation between body fat mass

150 and body fat-free mass using $\operatorname{LDAK}(\mathrm{v} 5.1)(15)$.

151

152 Severe COVID-19 and COVID-19 hospitalization outcomes

153 For proxy outcomes of COVID-19 severity, we adopted the outcomes of the COVID-19 Host

154 Genetics Initiative, which is an international consortium that works collaboratively to share

155 data and ideas, recruit patients, and disseminate scientific findings. The outcomes were

156 severe COVID-19 and COVID-19 hospitalization (16). For definitions of COVID-19 outcomes, 
medRxiv preprint doi: https://doi.org/10.1101/2022.01.20.22269593; this version posted January 21, 2022. The copyright holder for this preprint (which was not certified by peer review) is the author/funder, who has granted medRxiv a license to display the preprint in perpetuity.

It is made available under a CC-BY 4.0 International license.

157 the severe COVID-19 group was defined as individuals whose death was due to COVID-19,

158 those requiring respiratory support, or those requiring hospitalization due to symptoms related

159 to laboratory-confirmed SARS-CoV-2 infection. The COVID-19 hospitalization group was

160 defined as individuals requiring hospitalization due to symptoms associated with

161 laboratory-confirmed SARS-CoV-2 infection. We used the largest GWAS summary statistics

162 of the COVID-19 Host Genetics Initiative for severe COVID-19 and COVID-19 hospitalization

163 outcomes in individuals of European-ancestry, excluding those from the UK Biobank. We

164 restricted the population to those of European ancestry in order to minimize confounding due

165 to population stratification. The datasets corresponding to each outcome were as follows:

166 severe COVID-19 (cases: 4,792; controls: 1,054,664; dataset ID:

167 COVID19_HGI_A2_ALL_eur_leave_ukbb_23andme_20210107) and COVID-19

168 hospitalization (cases: 14,652; controls: 1,114,836; and dataset ID:

169 COVID19_HGI_B2_ALL_eur_leave_ukbb_23andme_20210622). For the definitions of

170 controls in the GWAS data, ancestry-matched controls were sourced from participating

171 population-based cohorts. Controls included individuals whose status of exposure to

172 SARS-CoV-2 was either negative according to electronic health records/questionnaires or

173 unknown (16).

174

175 Mendelian randomization 
medRxiv preprint doi: https://doi.org/10.1101/2022.01.20.22269593; this version posted January 21, 2022. The copyright holder for this preprint (which was not certified by peer review) is the author/funder, who has granted medRxiv a license to display the preprint in perpetuity.

It is made available under a CC-BY 4.0 International license .

176 We performed univariable MR using the inverse-variance weighted method (hereinafter

177 referred to as univariable MR) to evaluate the relationship of BMI, body fat percentage, body

178 fat mass, and body fat-free mass with severe COVID-19 and COVID-19 hospitalization.

179 Univariable MR is a weighted linear regression model in which the effect of genetic variants $i$

$180(i=1 \ldots n)$ on an outcome $\hat{\beta}_{Y_{i}}$ is regressed on the effect of the same genetic variant $i$ on the

181 exposure $\hat{\beta}_{X_{i}}$ weighted by the inverse of the squared standard error $\left(\operatorname{se}\left(\hat{\beta}_{Y_{i}}\right)^{-2}\right)$. The 182 estimated total effect $(\theta)$ of the exposure on the outcome can be formulated as follows:

The instrumental variable assumptions are: (I) Relevance: genetic variant is

185 associated with the exposure. (II) Independence: genetic variant does not share the

unmeasured cause or confounder with the outcome. (III) Exclusion restriction: genetic variant

187 does not influence the outcome except through the exposure $(6,7)$. These assumptions are

188 illustrated by a canonical diagram in Figure 2.

Multivariable MR was performed using the inverse-variance weighted method

190 (hereinafter referred to as multivariable MR). This is an extension of univariable MR, in which

191 the effects of genetic variant $i(i=1 \ldots n)$ on the outcome $\left(\hat{\beta}_{Y_{i}}\right)$ are regressed on the effect of

192 genetic variant $i$ on two exposures of $X_{1}$ (fat mass) and $X_{2}$ (fat-free mass). In multivariable MR,

193 genetic variants used as instrumental variables are associated with one or both of the

194 exposures (17). 
medRxiv preprint doi: https://doi.org/10.1101/2022.01.20.22269593; this version posted January 21, 2022. The copyright holder for this preprint (which was not certified by peer review) is the author/funder, who has granted medRxiv a license to display the preprint in perpetuity.

It is made available under a CC-BY 4.0 International license .

The causal associations were evaluated using odds ratios (ORs), which are

196 expressed according to a standard deviation (SD) increase in genetically predicted BMI

$197\left(\mathrm{~kg} / \mathrm{m}^{2}\right)$, body fat percentage (\%), body fat mass $(\mathrm{kg})$, or body fat-free mass $(\mathrm{kg})$.

198 Results with a $P<0.0125$ were considered statistically significant $(P=0.05 / 4$;

199 Bonferroni-corrected significance threshold according to the number of exposures). We note

200 that such a correction is likely overly conservative, given that the exposures are

201 non-independent. MR analyses were performed using TwoSampleMR (v0.5.6) in R (v4.02).

202 This study is conducted in accordance with the STROBE-MR guideline $(6,7)$. STROBE-MR

203 checklist is provided in Supplementary material (18).

205 Sensitivity analysis

206 We performed the MR-Egger intercept test, Cochran's Q test, and the MR-PRESSO global

207 test $(19,20)$ to detect horizontal pleiotropy, which occurs when instrumental variables

208 influence outcomes through pathways independent of the exposure. MR-Egger relaxes the

209 exclusion restriction assumption and is valid under the Instrument Strength Independent of

210 Direct Effect (InSIDE) assumption that associations of the genetic variants with the exposure

211 trait are independent of direct effects of the genetic variants on the outcome. Deviation of the

212 MR-Egger intercept from zero indicates horizontal pleiotropy. The results of Cochran's $Q$ test

213 were used to evaluate the heterogeneity of genetic variants used as instrumental variables. 
medRxiv preprint doi: https://doi.org/10.1101/2022.01.20.22269593; this version posted January 21, 2022. The copyright holder for this preprint (which was not certified by peer review) is the author/funder, who has granted medRxiv a license to display the preprint in perpetuity.

It is made available under a CC-BY 4.0 International license.

214 Results of Cochran's $Q$ test were presented with $I^{2}$ index, based on which the heterogeneity of

215 genetic variants was defined categorically with $I^{2}$ index as low $\left(I^{2}\right.$ index $\left.\leq 25 \%\right)$, moderate $\left(I^{2}\right.$

216 index 26-50\%), and high ( $I^{2}$ index $\left.>50 \%\right)$. Additionally, we performed the MR-PRESSO global

217 test, which can detect horizontally pleiotropic outlier SNPs. A significant result indicates the

218 presence of pleiotropic outlier SNPs and this method then generates ORs after removing and

219 correcting for these outliers (outlier-corrected ORs). MR-PRESSO can also be used to

220 evaluate the distortion of the causal estimates before and after the removal of pleiotropic

221 outlier SNPs following the MR-PRESSO distortion test. MR-PRESSO requires at least $50 \%$ of

222 the genetic variants to be valid instruments with no horizontal pleiotropy and also relies on the

223 InSIDE assumption.

224 Results with a $P<0.05$ were considered to indicate the presence of horizontal

225 pleiotropy for the MR-Egger intercept test, Cochran's Q test, MR-PRESSO global test, and

226 MR-PRESSO distortion test. Sensitivity analyses were performed with TwoSampleMR

227 (v.0.5.6) and MR-PRESSO (v1.0).

228

229 Ethics statements

230 The UK Biobank and COVID-19 Host Genetics Initiatives obtained ethics approval from the

231 relevant institutional ethics committees. We used publicly available summary statistics of 
medRxiv preprint doi: https://doi.org/10.1101/2022.01.20.22269593; this version posted January 21, 2022. The copyright holder for this preprint (which was not certified by peer review) is the author/funder, who has granted medRxiv a license to display the preprint in perpetuity. It is made available under a CC-BY 4.0 International license.

232 GWAS results of UK Biobank and COVID-19 Host Genetics Initiative and did not use

233 individual-level data.

234

235 Results

236 Instrumental variables for exposure traits

237 The characteristics of the exposure traits (BMI, body fat percentage, body fat mass, and body

238 fat-free mass) are presented in Table 1. The mean \pm SD BMI was $27.4 \pm 4.8 \mathrm{~kg} / \mathrm{m}^{2}$, body fat

239 percentage was $31.4 \pm 8.5 \%$, body fat mass was $24.9 \pm 9.6 \mathrm{~kg}$, and body fat-free mass was

$24053.2 \pm 11.5 \mathrm{~kg}$ (Table 1). For BMl, body fat percentage, body fat mass, and body fat-free mass,

$241439,377,417$, and 530 independent genome-wide significant SNPs were identified as

242 instrumental variables from the GWAS results of the UK Biobank, respectively. F-statistics for

243 these exposure traits were 507.6, 496.9, 502.2, and 607.4, respectively. The SNPs used as

244 instrumental variables are presented in Supplementary Table 1 (18).

246 Severe COVID-19 outcome

247 For the severe COVID-19 outcome (Figure 3), univariable MR showed that the genetically

248 predicted increase per SD in BMI, body fat percentage, and body fat mass was associated

249 with an increased risk of severe COVID-19 $\left(\mathrm{OR}_{\mathrm{BMI}}=1.49,95 \% \mathrm{Cl}: 1.19-1.87, P=5.57 \times 10^{-4}\right.$;

$250 \mathrm{OR}_{\text {fat percentage }}=1.94,95 \% \mathrm{Cl}: 1.41-2.67 ; P=5.07 \times 10^{-5}, \mathrm{OR}_{\text {body fat mass }}=1.61,95 \% \mathrm{Cl} 1.28-2.04$, 
medRxiv preprint doi: https://doi.org/10.1101/2022.01.20.22269593; this version posted January 21, 2022. The copyright holder for this preprint (which was not certified by peer review) is the author/funder, who has granted medRxiv a license to display the preprint in perpetuity.

It is made available under a CC-BY 4.0 International license .

$251 P=5.51 \times 10^{-5} ;$ and $\left.\mathrm{OR}_{\text {body fat-free mass }}=1.31,95 \% \mathrm{Cl}: 0.99-1.74, P=5.77 \times 10^{-2}\right)$. Further, as

252 instrumental variables for body fat mass and body fat-free mass were not independent from

253 each other $\left(r^{2}=0.64\right.$ for the genetic correlation of the two traits), we performed multivariable

254 MR to elucidate the independent causal effects of body fat mass and body fat-free mass on

255 the severe COVID-19 outcome, which showed that only body fat mass was independently

256 associated with the severe COVID 19 outcome (body fat mass: OR body fat mass $=2.91,95 \% \mathrm{Cl}$ :

$2571.71-4.96, P=8.85 \times 10^{-5}$, and $\left.\mathrm{OR}_{\text {body fat-free mass }}=1.02,95 \% \mathrm{Cl}: 0.61-1.67, P=0.945\right)$.

259 COVID-19 hospitalization outcome

260 For the COVID-19 hospitalization outcome (Figure 4), univariable MR showed that a

261 genetically predicted increase per SD in BMI, body fat percentage, body fat mass, and body

262 fat-free mass was associated with an increased risk of COVID-19 hospitalization $\left(\mathrm{OR}_{\mathrm{BMI}}=\right.$

$2631.31,95 \% \mathrm{Cl}: 1.19-1.44, P=3.46 \times 10^{-8} ; \mathrm{OR}_{\text {fat percentage }}=1.44,95 \% \mathrm{Cl}: 1.26-1.66, P=1.22 \times$

$26410^{-7} ; \mathrm{OR}_{\text {body fat mass }}=1.32,95 \% \mathrm{Cl}: 1.20-1.46, P=2.52 \times 10^{-8} ; \mathrm{OR}_{\text {body fat-free mass }}=1.2795 \% \mathrm{Cl}$ :

$2651.13-1.42, P=4.44 \times 10^{-5}$ ). In multivariable MR, only body fat mass was independently

266 associated with COVID-19 hospitalization $\left(\mathrm{OR}_{\text {body }}\right.$ fat mass $=2.38,95 \% \mathrm{Cl}: 1.56-3.61, P=$

$\left.2675.29 \times 10^{-5} ; \mathrm{OR}_{\text {body fat-free mass }}=0.82,95 \% \mathrm{Cl}: 0.56-1.19, P=0.293\right)$, consistent with the findings

268 for severe COVID-19. 
medRxiv preprint doi: https://doi.org/10.1101/2022.01.20.22269593; this version posted January 21, 2022. The copyright holder for this preprint (which was not certified by peer review) is the author/funder, who has granted medRxiv a license to display the preprint in perpetuity.

It is made available under a CC-BY 4.0 International license .

270 Sensitivity analysis

271 We performed MR-Egger, Cochran's Q test and MR-PRESSO for sensitivity analysis (Table

272 2). In the MR-Egger, the $95 \% \mathrm{Cl}$ results of the MR-Egger intercept (Egger-intercept) contained

273 the null hypothesis value zero for all exposure-outcome relationships, suggesting no evidence

274 of horizontal pleiotropy. Heterogeneity estimates of instrumental variables were low according

275 to the $I^{2}$ index ( $P^{2}$ index were $\leq 25 \%$ for all exposure traits). However, MR-PRESSO detected

276 some pleiotropic outlier SNPs in instrumental variables for BMI, body fat percentage, and

277 body fat mass with the COVID-19 hospitalization outcome $(P$-value for global test $<0.05)$.

278 Nevertheless, results with MR-PRESSO after removal and correction for these pleiotropic

279 outlier SNPs were directionally consistent with those from univariable MR, supporting the

280 robustness of the findings with univariable MR. In addition, the MR-PRESSO distortion test

281 detected no significant distortion in the causal estimates before and after removal of outlier

282 pleiotropic SNPs.

283

284 Discussion

285 To the best of our knowledge, this is the first MR study to evaluate the causal association

286 between directly measured body compositions (i.e., body fat percentage, body fat mass, and

287 body fat-free mass) with COVID-19 severity outcomes. In this study, we found that an increase

288 in BMI, body fat percentage, and body fat mass were associated with an increased risk of 
medRxiv preprint doi: https://doi.org/10.1101/2022.01.20.22269593; this version posted January 21, 2022. The copyright holder for this preprint (which was not certified by peer review) is the author/funder, who has granted medRxiv a license to display the preprint in perpetuity.

It is made available under a CC-BY 4.0 International license.

289 severe COVID-19 and COVID-19 hospitalization. We further evaluated the independent

290 causal effects of body fat mass and body fat-free mass on these outcomes and revealed that

291 only body fat mass was independently associated with the outcomes.

292 During the COVID-19 pandemic, obesity has emerged as a major risk factor for

293 COVID-19 outcomes. Multiple observational studies showed that obese individuals present an

294 increased risk of severe diseases, hospitalization, and death due to COVID-19 (2, 3, 21, 22).

295 However, observational studies are prone to confounding bias and reverse causation and do

296 not estimate the causal effects of exposures on outcomes. To overcome these limitations,

297 several MR studies have been performed to evaluate the causal relationship between

298 obesity-related traits and COVID-19 outcomes. Among anthropometric traits including BMI,

299 waist circumference, hip circumference, and waist-to-hip ratio, BMI showed an association

300 with poor COVID-19 outcomes (23). However, BMI is calculated only from height and weight

301 and does not consider body compositions. Moreover, these anthropometric traits are indirect

302 measures of obesity and might not be accurate proxies for body fat. Therefore, it is necessary

303 to evaluate associations between directly measured fat traits (i.e., body fat mass and body fat

304 percentage) and COVID-19 severity. In this MR study, we adopted these directly measured

305 traits as exposure traits and provided novel findings that indicate the causal association of

306 body fat accumulation with severe COVID-19 outcome. 
medRxiv preprint doi: https://doi.org/10.1101/2022.01.20.22269593; this version posted January 21, 2022. The copyright holder for this preprint (which was not certified by peer review) is the author/funder, who has granted medRxiv a license to display the preprint in perpetuity.

It is made available under a CC-BY 4.0 International license.

308 fat mass and fat-free mass, although some variants more strongly and proportionally influence

309 fat mass, whereas others influence fat-free mass more strongly. Therefore, multivariable MR

310 can test the differential causal effects of fat mass and fat-free mass. Using this approach,

311 recent MR studies showed differential associations between body fat mass and body fat-free

312 mass with various disorders (10-13). The present findings extend this knowledge to COVID-19.

313 Results from multivariable MR showed that body fat mass but not body fat-free mass was

314 independently associated with severe COVID-19 and COVID-19 hospitalization. The

315 association between body fat mass and COVID-19 severity was strengthened in multivariable

316 MR relative to findings using univariable MR, whereas the effects of body fat-free mass on

317 COVID-19 severity was markedly attenuated in multivariable MR, thereby illustrating the

318 independent associations between body fat mass and COVID-19 severity.

319 The underlying mechanism of these associations remains to be clarified. Obesity is a

320 metabolic disease characterized by systemic changes in metabolism, including insulin

321 resistance, glucose intolerance, dyslipidemia, changes in adipokines (e.g., increased leptin

322 and decreased adiponectin levels), chronic inflammation, and altered immune response, all of

323 which could collectively increase the risk of COVID-19 severity $(4,24,25)$. Moreover, obesity

324 causes respiratory dysfunction, including impaired respiratory physiology, increased airway

325 resistance, impaired gas exchange, low lung volume, and low muscle strength, which can also 
medRxiv preprint doi: https://doi.org/10.1101/2022.01.20.22269593; this version posted January 21, 2022. The copyright holder for this preprint (which was not certified by peer review) is the author/funder, who has granted medRxiv a license to display the preprint in perpetuity.

It is made available under a CC-BY 4.0 International license .

326 increase the risk of COVID-19 severity. Furthermore, the physical characteristics of obese

327 individuals render intubation and laryngoscopy difficult, which could also aggravate outcomes

328 (26). Further studies are needed to explore the pathways linking adiposity to increased risk of

329 COVID-19 severity.

This study has several strengths. We used an MR design, which minimized bias from

331 reverse causation and confounders, thereby enabling us to test for causal effects, provided

332 compliance with MR assumptions. In this MR study, we used the data from the UK Biobank for

333 the exposure traits ( $F$-statistics $>10$ for all exposure traits) and COVID-19 Host Genetics

334 Initiative for the outcomes, both of which have large sample sizes, thus increasing the

335 statistical power of the analysis. Furthermore, as proxy measures of body compositions, we

336 not only considered BMI, which is a common indirect measure, but also direct measures,

337 including body fat percentage, body fat mass, and body fat-free mass, and revealed

338 associations of these traits with COVD-19 severity.

339 However, our study also has important limitations. First, the MR analysis relies on

340 several key assumptions, the violation of which compromises causal inference. To test for

341 possible violations of these assumptions, we performed multiple sensitivity analyses. The

342 MR-Egger intercept test did not detect horizontal pleiotropy. Although SNP heterogeneities

343 were detected when analyzing the outcome in terms of COVID-19 hospitalizations, the

344 removal of outlier SNPs via MR-PRESSO still showed results consistent with those from MR 
medRxiv preprint doi: https://doi.org/10.1101/2022.01.20.22269593; this version posted January 21, 2022. The copyright holder for this preprint (which was not certified by peer review) is the author/funder, who has granted medRxiv a license to display the preprint in perpetuity.

It is made available under a CC-BY 4.0 International license .

345 with the inverse-variance method. We believe that these sensitivity analyses demonstrate the

346 robustness and validity of the present findings, however we acknowledge that horizontal

347 pleiotropy is difficult to exclude entirely. Second, regarding exposure traits, we used measures

348 derived from the bioelectrical impedance analysis (i.e., body fat percentage, body fat mass,

349 and body fat-free mass) instead of dual-energy X-ray absorptiometry (DXA)-derived

350 measures to maximize statistical power. Although the UK Biobank collected DXA-derived

351 measures for body fat mass, and body fat-free mass, the sample size was markedly smaller

352 for these measurements $(n=5,170)$. Moreover, although DXA-derived measures are

353 generally more accurate than impedance-derived measures, high correlations between the

354 two were reported for fat mass $(r=0.96)$ and fat-free mass $(r=0.86)$ in the UK Biobank

355 dataset (10). Hence, we believe impedance-derived measures can serve as clinically-relevant

356 exposure traits in the present analysis. Third, we only used summary-level data and did not

357 use individual-level data. Therefore, we could not evaluate the nonlinear relationship between

358 exposures and outcomes. However, it should be noted that MR using summary statistics can

359 still test for the presence of causal effects of exposures on outcomes, even if the

360 exposure-outcome relationship is nonlinear (27). Additionally, a recent prospective cohort

361 study of 6.9 million individuals in the UK suggested that BMI and COVID-19 severity show a

362 linear relationship within a BMI range $\geq 23 \mathrm{~kg} / \mathrm{m}^{2}(2)$. Notably, the BMI of a majority of the

363 individuals in the UK Biobank population included in the present analysis fell within this range 
medRxiv preprint doi: https://doi.org/10.1101/2022.01.20.22269593; this version posted January 21, 2022. The copyright holder for this preprint (which was not certified by peer review) is the author/funder, who has granted medRxiv a license to display the preprint in perpetuity.

It is made available under a CC-BY 4.0 International license .

$364\left(\geq 23 \mathrm{~kg} / \mathrm{m}^{2}\right)$. Fourth, we restricted our analysis to individuals of European ancestry given that

365 majority of participants in the UK Biobank were of European ancestry. Future studies are

366 warranted to evaluate the generalizability of our findings to other populations.

367 In summary, the present MR study provides evidence that indicates a causal

368 relationship between body fat accumulation and COVID-19 severity. Because excess fat can

369 be reduced by following an appropriate diet and exercising, it might represent an important

370 modifiable risk factor. Thus, body weight reduction considering direct measurements of body

371 fat (i.e., body fat percentage and body fat mass) can be an effective strategy to reduce the risk

372 of COVID-19 severity.

374 Acknowledgments

375 The Richards research group is supported by the Canadian Institutes of Health Research

376 (CIHR: 365825; 409511, 100558, 169303), the McGill Interdisciplinary Initiative in Infection

377 and Immunity (MI4), the Lady Davis Institute of the Jewish General Hospital, the Jewish

378 General Hospital Foundation, the Canadian Foundation for Innovation, the NIH Foundation,

379 Cancer Research UK, Genome Québec, the Public Health Agency of Canada, McGill

380 University, Cancer Research UK [grant umber C18281/A29019] and the Fonds de Recherche

381 Québec Santé (FRQS). JBR is supported by a FRQS Mérite Clinical Research Scholarship.

382 Support from Calcul Québec and Compute Canada is acknowledged. TwinsUK is funded by 
medRxiv preprint doi: https://doi.org/10.1101/2022.01.20.22269593; this version posted January 21, 2022. The copyright holder for this preprint

(which was not certified by peer review) is the author/funder, who has granted medRxiv a license to display the preprint in perpetuity.

It is made available under a CC-BY 4.0 International license.

383 the Welcome Trust, Medical Research Council, European Union, the National Institute for

384 Health Research (NIHR)-funded BioResource, Clinical Research Facility and Biomedical

385 Research Centre based at Guy's and St Thomas' NHS Foundation Trust in partnership with

386 King's College London. These funding agencies had no role in the design, implementation or

387 interpretation of this study. SY and HM are supported by the Japan Society for the Promotion

388 of the Science.

389

390 Data availability

391 All GWAS summary statistics used in this study are publicly available. All results are included

392 in the present article. 
medRxiv preprint doi: https://doi.org/10.1101/2022.01.20.22269593; this version posted January 21, 2022. The copyright holder for this preprint

(which was not certified by peer review) is the author/funder, who has granted medRxiv a license to display the preprint in perpetuity.

It is made available under a CC-BY 4.0 International license .

394 1. World Health Organization. COVID-19 clinical management: living guidance.

395 https://www.who.int/publications/i/item/WHO-2019-nCoV-clinical-2021-1 Accessed on 15

396 Nov, 2021.

397 2. Gao M, Piernas C, Astbury NM, Hippisley-Cox, J, O’Rahilly, S, Aveyard, P, Jebb SA.

398 Associations between body-mass index and COVID-19 severity in 6.9 million people in

399 England: a prospective, community-based, cohort study. Lancet Diabetes Endocrinol.

$400 \quad 2021 ; 9(6): 350-359$.

401 3. Recalde M, Pistillo A, Fernandez-Bertolin S, Roel E, Aragon M, Freisling H,

402 Prieto-Alhambra D, Burn E, Duarte-Salles T. Body mass index and risk of COVID-19

403 diagnosis, hospitalisation, and death: a cohort study of 2524926 Catalans. J Clin Endocrinol

404 Metab. 2021;106(12):e5030-e5042.

405 4. Recalde M, Roel E, Pistillo A, Sena AG, Prats-Uribe A, Ahmed WU, Alghoul H,

406 Alshammari TM, Alser O, Areia C, Burn E, Casajust P, Dawoud D, DuVall SL, Falconer T,

407 Fernández-Bertolín S, Golozar A, Gong M, Lai LYH, Lane JCE, Lynch KE, Matheny ME,

408 Mehta PP, Morales DR, Natarjan K, Nyberg F, Posada JD, Reich CG, Rijnbeek PR, Schilling

409 LM, Shah K, Shah NH, Subbian V, Zhang L, Zhu H, Ryan P, Prieto-Alhambra D, Kostka K,

410 Duarte-Salles T. Characteristics and outcomes of 627044 COVID-19 patients living with and 
medRxiv preprint doi: https://doi.org/10.1101/2022.01.20.22269593; this version posted January 21, 2022. The copyright holder for this preprint (which was not certified by peer review) is the author/funder, who has granted medRxiv a license to display the preprint in perpetuity.

It is made available under a CC-BY 4.0 International license.

411 without obesity in the United States, Spain, and the United Kingdom. Int J Obes.

$412 \quad 2021 ; 45(11): 2347-2357$.

413 5. Grimes DA, Schulz KF. Bias and causal associations in observational research.

414 Lancet. 2002;359(9302):248-252.

415 6. Skrivankova VW, Richmond RC, Woolf BAR, Yarmolinsky J, Davies NM, Swanson

416 SA, Vanderweele TJ, Higgins JPT, Timpson NJ, Dimou N, Langenberg C, Golub RM, Loder

417 EW, Gallo V, Tybjaerg-Hansen A, Davey Smith G, Egger M, Richards JB. Strengthening the

418 Reporting of Observational Studies in Epidemiology Using Mendelian Randomization. JAMA.

$4192021 ; 326(16): 1614$.

$4207 . \quad$ Skrivankova VW, Richmond RC, Woolf BAR, Davies NM, Swanson SA,

421 VanderWeele TJ, Timpson NJ, Higgins JPT, Dimou N, Langenberg C, Loder EW, Golub RM,

422 Egger M, Davey Smith G, Richards JB. Strengthening the reporting of observational studies

423 in epidemiology using mendelian randomisation (STROBE-MR): explanation and elaboration.

424 BMJ. 2021;375:n2233.

425 8. Rothman KJ. BMI-related errors in the measurement of obesity. Int J Obes.

426 2008;32(S3):S56-S59.

427 9. Rask-Andersen M, Karlsson T, Ek WE, Johansson Å. Genome-wide association

428 study of body fat distribution identifies adiposity loci and sex-specific genetic effects. Nat

429 Commun. 2019;10(1):339. 
medRxiv preprint doi: https://doi.org/10.1101/2022.01.20.22269593; this version posted January 21, 2022. The copyright holder for this preprint (which was not certified by peer review) is the author/funder, who has granted medRxiv a license to display the preprint in perpetuity.

It is made available under a CC-BY 4.0 International license.

430 10. Tikkanen E, Gustafsson S, Knowles JW, Perez M, Burgess S, Ingelsson E. Body

431 composition and atrial fibrillation: a Mendelian randomization study. Eur Heart J.

$432 \quad 2019 ; 40(16): 1277-1282$.

433 11. Larsson SC, Bäck M, Rees JMB, Mason AM, Burgess S. Body mass index and body

434 composition in relation to 14 cardiovascular conditions in UK Biobank: a Mendelian

435 randomization study. Eur Heart J. 2020;41(2):221-226.

436 12. Zeng H, Lin C, Wang S, Zheng Y, Gao X. Genetically predicted body composition in

437 relation to cardiometabolic traits: a Mendelian randomization study. Eur J Epidemiol.

$438 \quad 2021 ; 36(11): 1157-1168$.

439 13. Speed MS, Jefsen $\mathrm{OH}$, Børglum AD, Speed D, Østergaard SD. Investigating the

440 association between body fat and depression via Mendelian randomization. Trans/ Psychiatry.

$441 \quad 2019 ; 9(1): 184$.

442 14. Hemani G, Zheng J, Elsworth B, Wade KH, Haberland V, Baird D, Laurin C, Burgess

443 S, Bowden J, Langdon R, Tan VY, Yarmolinsky J, Shihab HA, Timpson NJ, Evans DM,

444 Relton C, Martin RM, Davey Smith G, Gaunt TR, Haycock PC. The MR-Base platform

445 supports systematic causal inference across the human phenome. eLife. 2018;7:e34408.

446 15. Speed D, Holmes J, Balding DJ. Evaluating and improving heritability models using

447 summary statistics. Nat Genet. 2020;52(4):458-462. 
medRxiv preprint doi: https://doi.org/10.1101/2022.01.20.22269593; this version posted January 21, 2022. The copyright holder for this preprint (which was not certified by peer review) is the author/funder, who has granted medRxiv a license to display the preprint in perpetuity.

It is made available under a CC-BY 4.0 International license.

448 16. COVID-19 Host Genetics Initiative. Mapping the human genetic architecture of

449 COVID-19. Nature. 2021;600(7889):472-477.

450 17. Zuber V, Colijn JM, Klaver C, Burgess S. Selecting likely causal risk factors from

451 high-throughput experiments using multivariable Mendelian randomization. Nat Commun.

$452 \quad 2020 ; 11(1): 29$.

453 18. Yoshiji S, Tanaka D, Minamino H, Murakami T, Fujita Y, Richards JB, Inagaki N.

454 Supplementary material for "Causal association between body fat accumulation and

455 COVID-19 severity: A Mendelian randomization study". Figshare. Deposited Jan 7, 2022.

456 https://figshare.com/s/c876361a354038ea988f.

457 19. Bowden J, Davey Smith G, Burgess S. Mendelian randomization with invalid

458 instruments: effect estimation and bias detection through Egger regression. Int J Epidemiol.

$4592015 ; 44(2): 512-525$.

460 20. Verbanck M, Chen C-Y, Neale B, Do R. Detection of widespread horizontal

461 pleiotropy in causal relationships inferred from Mendelian randomization between complex

462 traits and diseases. Nat Genet. 2018;50(5):693-698.

463 21. Hippisley-Cox J, Coupland CA, Mehta N, Keogh RH, Diaz-Ordaz K, Khunti K, Lyons

464 RA, Kee F, Sheikh A, Rahman S, Valabhji J, Harrison EM, Sellen P, Haq N, Semple MG,

465 Johnson PWM, Hayward A, Nguyen-Van-Tam JS. Risk prediction of covid-19 related death 
medRxiv preprint doi: https://doi.org/10.1101/2022.01.20.22269593; this version posted January 21, 2022. The copyright holder for this preprint (which was not certified by peer review) is the author/funder, who has granted medRxiv a license to display the preprint in perpetuity.

It is made available under a CC-BY 4.0 International license .

466 and hospital admission in adults after covid-19 vaccination: national prospective cohort study.

467 BMJ. 2021;374:n2244.

468 22. Steenblock C, Schwarz PEH, Ludwig B, Linkermann A, Zimmet P, Kulebyakin K,

469 Tkachuk VA, Markov AG, Lehnert H, de Angelis MH, Rietzsch H, Rodionov RN, Khunti K,

470 Hopkins D, Birkenfeld AL, Boehm B, Holt RIG, Skyler JS, DeVries JH, Renard E, Eckel RH,

471 Alberti KGMM, Geloneze B, Chan JC, Mbanya JC, Onyegbutulem HC, Ramachandran A,

472 Basit A, Hassanein M, Bewick G, Spinas GA, Beuschlein F, Landgraf R, Rubino F, Mingrone

473 G, Bornstein SR. COVID-19 and metabolic disease: mechanisms and clinical management.

474 Lancet Diabetes Endocrinol. 2021;9(11):786-798.

475 23. Aung N, Khanji MY, Munroe PB, Petersen SE. Causal inference for genetic obesity,

476 cardiometabolic profile and COVID-19 susceptibility: a Mendelian randomization study. Front

477 Genet. 2020;11:586308.

478 24. Gammone MA, D'Orazio N. Review: obesity and COVID-19: a detrimental

479 intersection. Front Endocrinol (Lausanne). 2021;12:652639.

480 25. Foulkes AS, Selvaggi C, Shinnick D, Lumish H, Kim E, Cao T, Thaweethai T, Qian J,

481 Lu F, Yan J, Cheng D, He W, Clerkin KJ, Madhavan MV, Meigs JB, Triant VA, Lubitz SA,

482 Gupta A, Bassett IV, Reilly MP. Understanding the link between obesity and severe

483 COVID-19 outcomes: Causal mediation by systemic inflammatory response. J Clin

484 Endocrinol Metab. 2021;dgab629. https://doi.org/10.1210/clinem/dgab629. 
medRxiv preprint doi: https://doi.org/10.1101/2022.01.20.22269593; this version posted January 21, 2022. The copyright holder for this preprint (which was not certified by peer review) is the author/funder, who has granted medRxiv a license to display the preprint in perpetuity. It is made available under a CC-BY 4.0 International license .

485 26. Stefan N, Birkenfeld AL, Schulze MB, Ludwig DS. Obesity and impaired metabolic

486 health in patients with COVID-19. Nat Rev Endocrinol. 2020;16(7):341-342.

487 27. Burgess S, Davies NM, Thompson SG. Instrumental variable analysis with a

488 nonlinear exposure-outcome relationship. Epidemiology. 2014;25(6):877-885. 
medRxiv preprint doi: https://doi.org/10.1101/2022.01.20.22269593; this version posted January 21, 2022. The copyright holder for this preprint (which was not certified by peer review) is the author/funder, who has granted medRxiv a license to display the preprint in perpetuity. It is made available under a CC-BY 4.0 International license.

Table 1. Dataset descriptions.

\begin{tabular}{|c|c|c|c|c|}
\hline Data source & Dataset details & Phenotype & $\begin{array}{c}\text { Sample size } \\
\text { of each dataset }\end{array}$ & Mean \pm SD \\
\hline \multirow{4}{*}{ UK Biobank } & \multirow{4}{*}{$\begin{array}{l}\text { - GWAS in individuals } \\
\text { of European ancestry. } \\
\text { - Body fat and body } \\
\text { fat-free mass were } \\
\text { measured using } \\
\text { bioelectrical } \\
\text { impedance analysis. }\end{array}$} & Body mass index & 461,460 & $\begin{array}{c}27.4 \pm 4.8 \\
\mathrm{~kg} / \mathrm{m}^{2}\end{array}$ \\
\hline & & $\begin{array}{c}\text { Body fat } \\
\text { percentage }\end{array}$ & 454,633 & $31.4 \pm 8.5 \%$ \\
\hline & & Body fat mass & 454,137 & $24.9 \pm 9.6 \mathrm{~kg}$ \\
\hline & & $\begin{array}{c}\text { Body fat-free } \\
\text { mass }\end{array}$ & 454,850 & $\begin{array}{c}53.2 \pm 11.5 \\
\mathrm{~kg}\end{array}$ \\
\hline \multirow{2}{*}{$\begin{array}{c}\text { COVID-19 } \\
\text { Host Genetics } \\
\text { Initiative }\end{array}$} & \multirow{2}{*}{$\begin{array}{l}\text { - Meta-analysis of } \\
\text { GWAS in individuals of } \\
\text { European ancestry } \\
\text { excluding those from } \\
\text { UK biobank }\end{array}$} & $\begin{array}{c}\text { Severe } \\
\text { COVID-19 }\end{array}$ & $\begin{array}{c}\text { Cases: } 4,792 \\
\text { Controls: } 1,054,664\end{array}$ & - \\
\hline & & $\begin{array}{c}\text { COVID-19 } \\
\text { hospitalization }\end{array}$ & $\begin{array}{c}\text { Cases: } 14,652 \\
\text { Controls: } 1,114,836\end{array}$ & - \\
\hline
\end{tabular}

490 
medRxiv preprint doi: https://doi.org/10.1101/2022.01.20.22269593; this version posted January 21, 2022. The copyright holder for this preprint (which was not certified by peer review) is the author/funder, who has granted medRxiv a license to display the preprint in perpetuity.

It is made available under a CC-BY 4.0 International license.

\section{1}

491 Table 2. Sensitivity analysis results.

\begin{tabular}{|c|c|c|c|c|c|c|c|c|c|c|}
\hline \multirow{3}{*}{ Exposures } & \multirow{3}{*}{ Outcomes } & \multicolumn{9}{|c|}{ Sensitivity analysis methods } \\
\hline & & \multicolumn{4}{|c|}{ MR-Egger } & \multirow{2}{*}{$\begin{array}{c}\text { Cochran's } \\
\text { Q test } \\
\text { Pindex }\end{array}$} & \multicolumn{4}{|c|}{ MR-PRESSO } \\
\hline & & $\begin{array}{l}\text { Egger slope } \\
\qquad(95 \% \mathrm{Cl})\end{array}$ & $\begin{array}{c}P \text {-value } \\
\text { (Egger slope) }\end{array}$ & $\begin{array}{l}\text { Egger intercept } \\
\qquad(95 \% \mathrm{Cl})\end{array}$ & $\begin{array}{c}P \text {-value } \\
\text { (Egger } \\
\text { intercept) }\end{array}$ & & $\begin{array}{c}\text { Global test } \\
P \text {-value }\end{array}$ & $\begin{array}{c}\text { Outlier-corrected } \\
\text { OR }(95 \% \mathrm{Cl})\end{array}$ & $\begin{array}{c}\text { Outlier-corrected } \\
\qquad P \text {-value }\end{array}$ & $\begin{array}{c}\text { Distortion test } \\
P \text {-value }\end{array}$ \\
\hline $\begin{array}{l}\text { Body mass } \\
\text { index }\end{array}$ & \multirow{4}{*}{$\begin{array}{l}\text { Severe } \\
\text { COVID-19 }\end{array}$} & $\begin{array}{c}1.24 \\
(0.65-2.37)\end{array}$ & 0.523 & $\begin{array}{c}0.004 \\
(-0.008-0.015)\end{array}$ & 0.542 & 1.8 & 0.417 & No outlier & - & - \\
\hline $\begin{array}{c}\text { Body fat } \\
\text { percentage }\end{array}$ & & $\begin{array}{c}1.79 \\
(0.62-5.14)\end{array}$ & 0.282 & $\begin{array}{c}0.001 \\
(-0.013-0.016)\end{array}$ & 0.874 & 9.7 & 0.108 & No outlier & - & - \\
\hline $\begin{array}{l}\text { Body } \\
\text { fat mass }\end{array}$ & & $\begin{array}{c}1.63 \\
(0.84-3.15)\end{array}$ & 0.147 & $\begin{array}{c}-0.0002 \\
(-0.012-0.012)\end{array}$ & 0.975 & 4.0 & 0.273 & No outlier & - & - \\
\hline $\begin{array}{l}\text { Body } \\
\text { fat-free mass }\end{array}$ & & $\begin{array}{c}0.74 \\
(0.38-1.45)\end{array}$ & 0.378 & $\begin{array}{c}0.009 \\
(-0.001-0.018)\end{array}$ & 0.066 & 5.0 & 0.551 & No outlier & - & - \\
\hline $\begin{array}{l}\text { Body mass } \\
\text { index }\end{array}$ & \multirow{4}{*}{$\begin{array}{c}\text { COVID-19 } \\
\text { hospitalization }\end{array}$} & $\begin{array}{c}1.27 \\
(0.99-1.64)\end{array}$ & $6.34 \times 10^{-2}$ & $\begin{array}{c}0.001 \\
(-0.004-0.005)\end{array}$ & 0.812 & 19.5 & 0.001 & $\begin{array}{c}1.3085 \\
(1.3082-1.3088)\end{array}$ & $7.09 \times 10^{-9}$ & 0.864 \\
\hline $\begin{array}{c}\text { Body fat } \\
\text { percentage }\end{array}$ & & $\begin{array}{c}1.80 \\
(1.17-2.76)\end{array}$ & $8.04 \times 10^{-3}$ & $\begin{array}{c}-0.003 \\
(-0.009-0.003)\end{array}$ & 0.297 & 18.4 & 0.003 & $\begin{array}{c}1.4498 \\
(1.4493-1.4503)\end{array}$ & $1.60 \times 10^{-7}$ & 0.810 \\
\hline $\begin{array}{l}\text { Body } \\
\text { fat mass }\end{array}$ & & $\begin{array}{c}1.53 \\
(1.17-2.00)\end{array}$ & $2.31 \times 10^{-3}$ & $\begin{array}{c}-0.003 \\
(-0.008-0.002)\end{array}$ & 0.264 & 17.3 & 0.004 & $\begin{array}{c}1.3351 \\
(1.3348-1.3353)\end{array}$ & $3.98 \times 10^{-3}$ & 0.881 \\
\hline $\begin{array}{l}\text { Body } \\
\text { fat-free mass }\end{array}$ & & $\begin{array}{c}1.12 \\
(0.85-1.46)\end{array}$ & 0.433 & $\begin{array}{c}0.002 \\
(-0.002-0.006)\end{array}$ & 0.302 & 12.3 & 0.174 & No outlier & - & - \\
\hline
\end{tabular}

492 
medRxiv preprint doi: https://doi.org/10.1101/2022.01.20.22269593; this version posted January 21, 2022. The copyright holder for this preprint

(which was not certified by peer review) is the author/funder, who has granted medRxiv a license to display the preprint in perpetuity.

It is made available under a CC-BY 4.0 International license.

493 Figure legends

494

495 Figure 1. Schematic representation of the Mendelian randomization study.

496 SNPs = single nucleotide polymorphisms.

497 Figure 2. Canonical diagram illustrating the instrumental variable assumptions made in the

498 Mendelian randomization analyses.

499 Genetic variant $\boldsymbol{G}$ is used as an instrumental variable for exposure $\boldsymbol{X}$ (body mass index, body

500 fat percentage, body fat mass, or body fat-free mass) to evaluate the causal effect of $\boldsymbol{X}$ on the

501 outcome $\boldsymbol{Y}$ (severe COVID-19 or COVID-19 hospitalization). Instrumental variable

502 assumptions include: (I) Relevance: genetic variant $\boldsymbol{G}$ is associated with exposure $\boldsymbol{X}$. (II)

503 Independence: genetic variant $\mathbf{G}$ does not share the unmeasured cause or the confounder

504 with the outcome $\boldsymbol{Y}$. (III) Exclusion restriction: genetic variant $\boldsymbol{G}$ does not influence the

505 outcome $\boldsymbol{Y}$ except through the exposure $\boldsymbol{X}$.

506 Red solid arrows represent causal effects; grey solid arrows represent causal effects of the

507 unmeasured cause or confounder that do not violate the instrumental variable assumptions;

508 dashed arrows represent causal effects that are specifically prohibited by the instrumental

509 variable assumptions. 
medRxiv preprint doi: https://doi.org/10.1101/2022.01.20.22269593; this version posted January 21, 2022. The copyright holder for this preprint (which was not certified by peer review) is the author/funder, who has granted medRxiv a license to display the preprint in perpetuity. It is made available under a CC-BY 4.0 International license.

511 Figure 3. Univariable and multivariable Mendelian randomization analysis of the severe

512 COVID-19 outcome.

$513 \mathrm{MR}=$ Mendelian randomization.

514

515 Figure 4. Univariable and multivariable Mendelian randomization analysis for the COVID-19

516 hospitalization outcome.

$517 \quad$ MR $=$ Mendelian randomization. 
Figure 1. Schematic representation of the Mendelian randomization study.

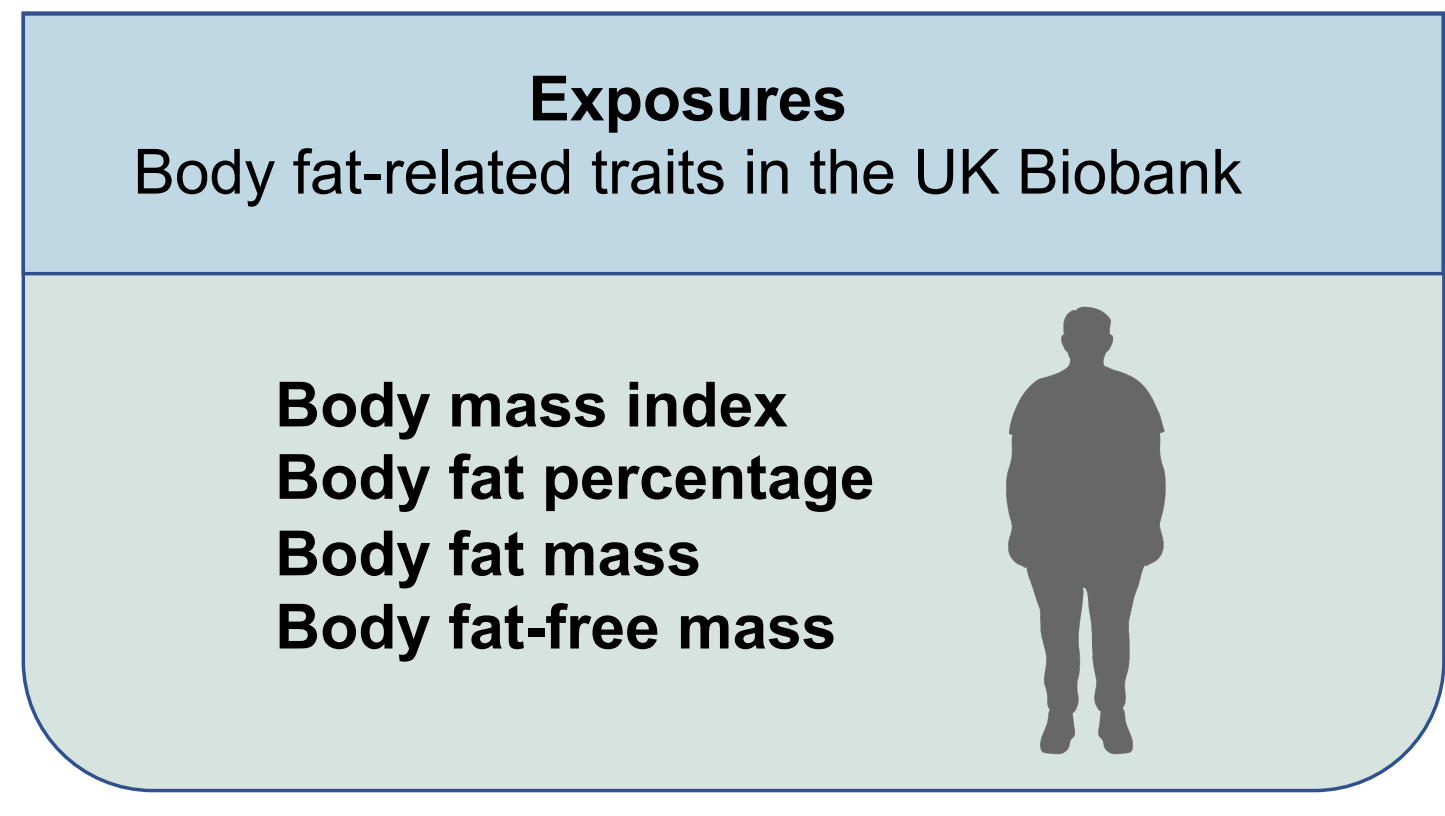

Select SNPs as instrumental variables for

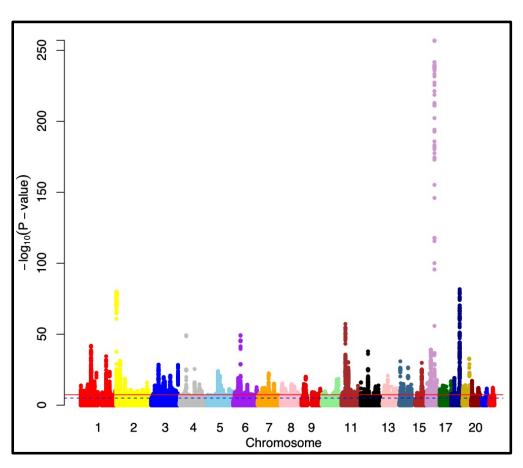

Genome-wide association studies exposures

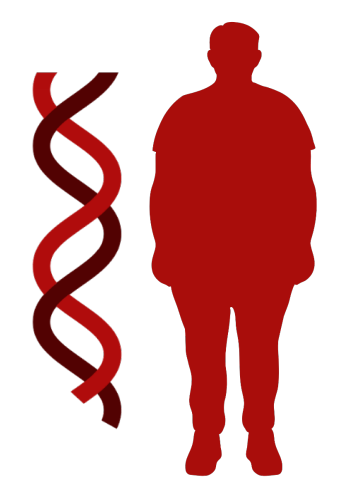

SNPs associated with

a higher or lower exposure

\section{Outcomes}

COVID-19 severity outcomes in the COVID-19 Host Genetics Initiative

Severe COVID-19

COVID-19 hospitalization

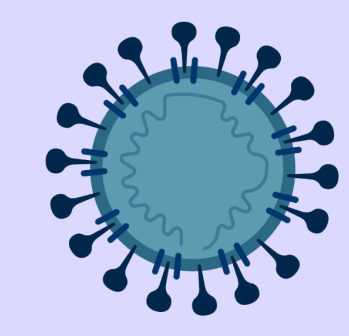

Causal inference with Mendelian randomization
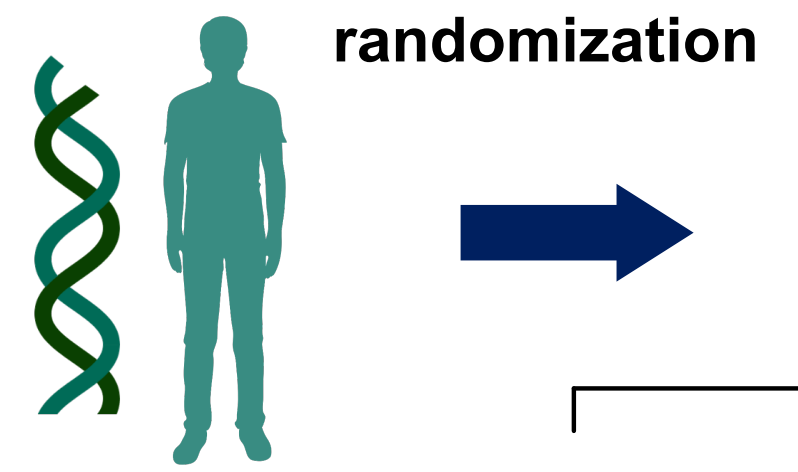

\section{Odds ratios}


Figure 2. Canonical diagram illustrating the instrumental variable assumptions made in the Mendelian randomization analyses.

(II) Independence

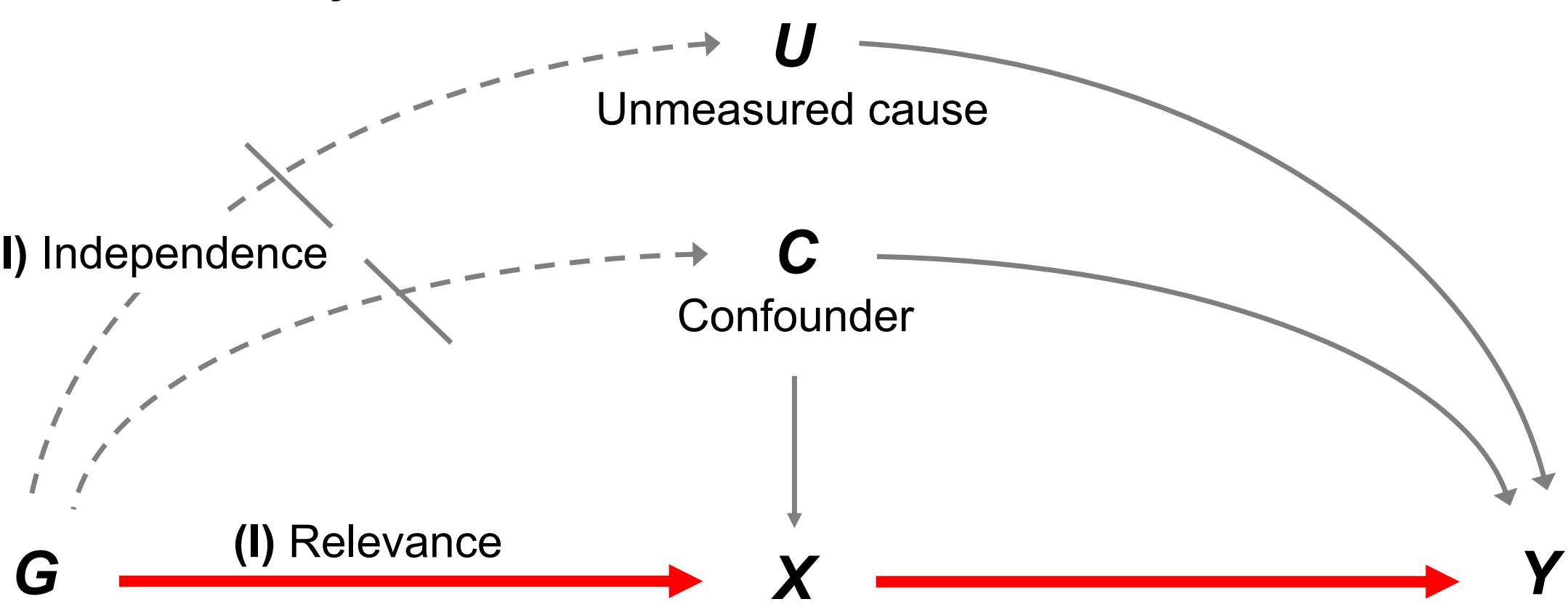

Outcome

Genetic variant

Exposure

$\$$

Body mass index

Body fat percentage

Body fat mass

Body fat-free mass

(III) Exclusion restriction

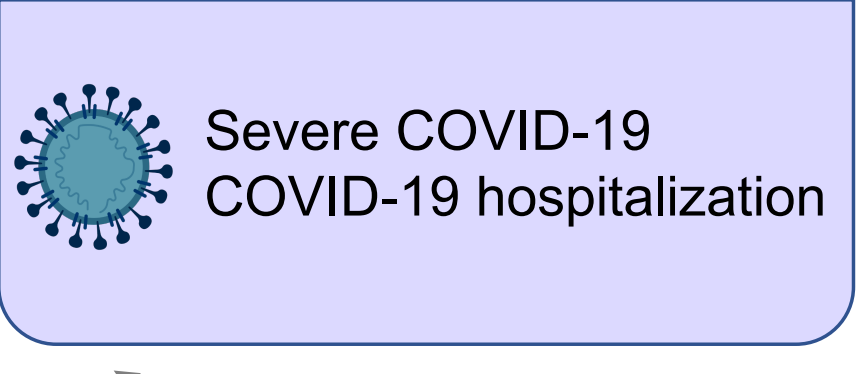


Figure 3. Severe COVID-19 outcome.

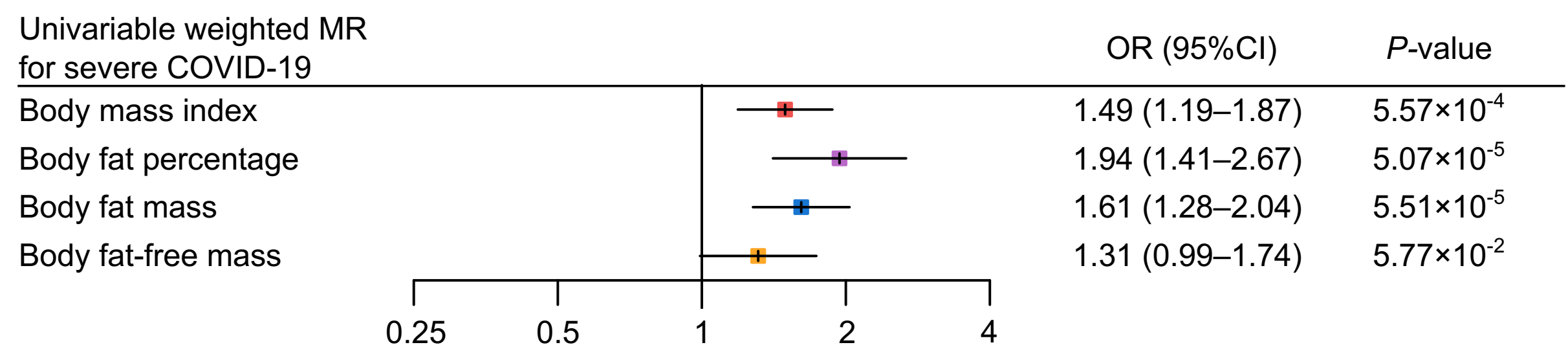

Multivariable weighted MR for severe COVID-19 Body fat mass Body fat-free mass

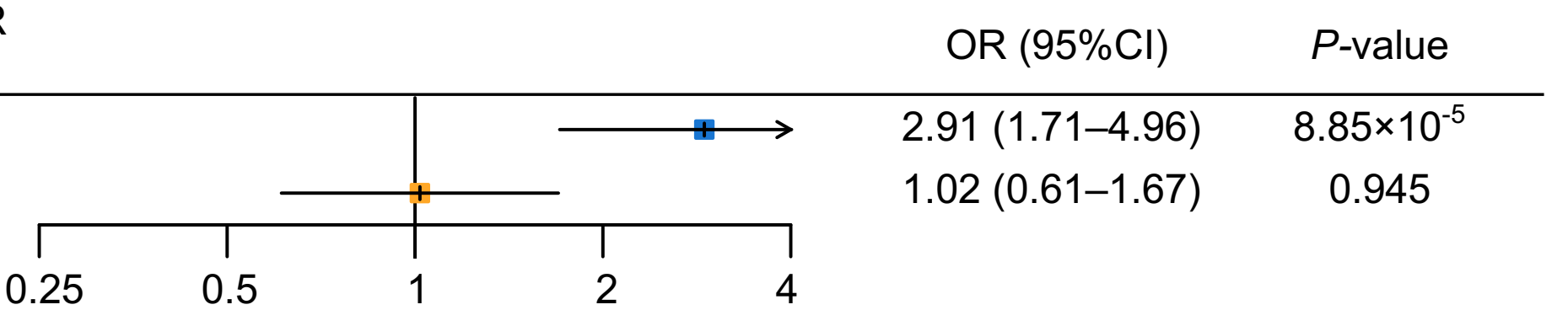


Figure 4. COVID-19 hospitalization outcome.

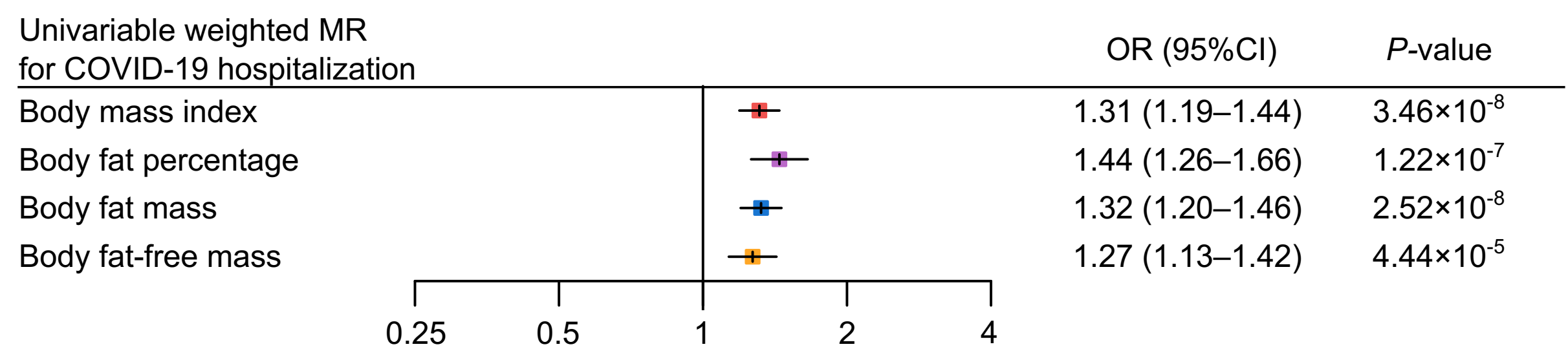

Multivariable weighted MR for COVID-19 hospitalization Body fat mass Body fat-free mass

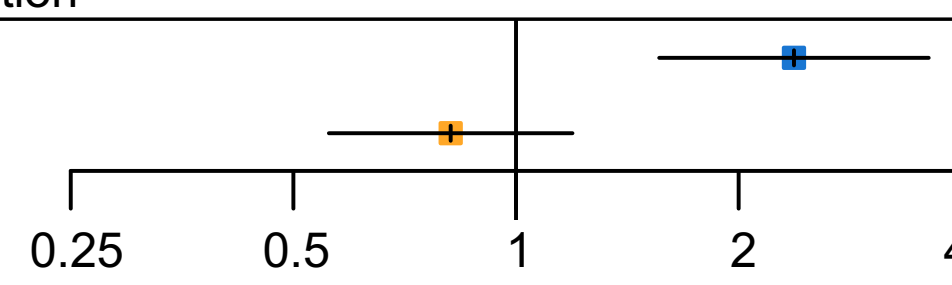

\begin{tabular}{cc} 
OR $(95 \% \mathrm{Cl})$ & $P$-value \\
\hline $2.38(1.56-3.61)$ & $5.29 \times 10^{-5}$ \\
$0.82(0.56-1.19)$ & 0.293
\end{tabular}

